\title{
MINERAL RESOURCE POTENTIAL OF THE DEVILS FORK ROADLESS AREA, SCOTT COUNTY, VIRGINIA
}

\author{
By \\ Kenneth J. Englund and Wayne R. Sigleo, U.S. Geological Survey \\ and
}

Paul T. Behum, U.S. Bureau of Mines

1983

Studies Related To Wilderness

Under the provisions of the Wilderness Act (Public Law 88-577, September 3, 1964) and related acts, the U.S. Geological Survey and the U.S. Bureau of Mines have been conducting mineral surveys of wilderness and primitive areas. Areas officially designated as "wilderness," "wild," or "canoe" when the act was passed were incorporated into the National Wilderness Preservation System and some of them are presently being studied. The act provided that areas under consideration for wilderness designation should be studied for suitability for incorporation into the Wilderness System. The mineral surveys constitute one aspect of the suitability studies. The act directs that the results of such surveys are to be made available to the public and be submitted to the President and the Congress. This report discusses the results of a mineral survey of the Devils Fork Roadless Area, Scott County, Va. The area was classified as a further planning area during the Second Roadless Area Review and Evaluation (RARE II) by the U.S. Forest Service, January 1979.

\section{MINERAL RESOURCE POTENTIAL SUMMARY STATEMENT}

The Devils Fork Roadless Area contains approximately 5,837 acres in the Clinch Ranger District, Jefferson National Forest in southwestern Virginia. Surface rights for about $\mathbf{8 0}$ percent of the area are owned by the U.S. Government. The remaining surface acreage and all of the mineral rights are in private ownership. The area is in the Cumberland Mountain section of the Appalachian Plateaus physiographic province within an easterly prong of the Appalachian coal region.

Sandstone and shale of Late Mississippian age crop out locally along the eastern edge and underlie the entire area to the northwest. Coal-bearing rocks of Early Pennsylvanian age crop out on the southeastern limb of the Powell Valley anticline in the rest of the area.

Coal is the most important mineral resource in the study area. It is ranked as high-volatile A bituminous coal, and like most of the coal in nearby mining areas, is suitable for use in steam generation and for the manufacture of metallurgical coke. Remaining coal resources are estimated to total 35 million short tons, of which 4.57 million short tons are included in the reserve base. Demonstrated coal reserves are 2.83 million short tons, of which 2.70 million short tons are recoverable by underground mining, and an additional 0.13 million short tons are recoverable by surface mining methods.

Other mineral resources in the Devils Fork Roadless Area include limestone, shale, clay, and sandstone. The Greenbrier Limestone, which crops out immediately southeast of the area, is suitable for road metal, construction aggregate, and high-calcium limestone. Preliminary tests indicate that local shale is suitable for structural-clay products and possible lightweight aggregate. Some sandstone may be suitable for rough building stone, crushed roadstone, and construction sand.

Nearby drilling results indicate that the natural gas potential is moderate to high and the oil potential is low in the roadless area. No evidence of a potential was found for metallic mineral resources.

\section{INTRODUCTION}

The Devils Fork Roadless Area is in Clinch Ranger district of the Jefferson National Forest, southwestern Virginia. It is located in Scott County, about $5 \mathrm{mi}$ southeast of Big Stone Gap, Va., and is accessible from there via U.S. 23 to Duffield, Va., and then northeastward along State Route 653 (fig. 1). Access from the north is provided by State Routes 616 and 619 and Forest Route 237. Southern access is provided by State Routes 619 and 649 . The interior is accessible by foot along overgrown logging railroad grades and abandoned forest roads on the lower portions of Devil Fork, Straight Fork, and Roddy Branch.

The Devils Fork Roadless Area is located at the eastern edge of the Appalachian coal region and is within the Cumberland Mountain section of the 

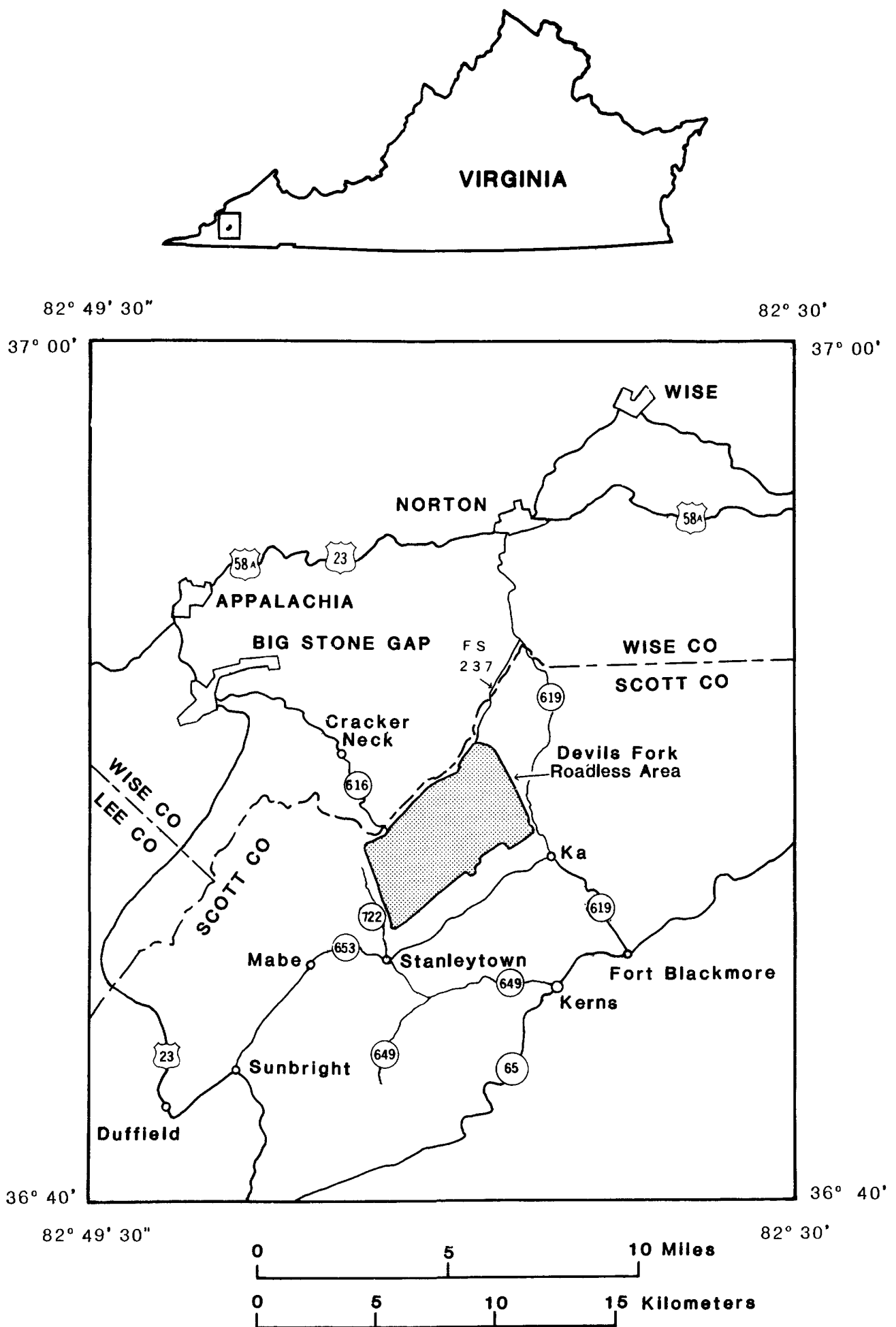

Figure 1--Index map showing the location of the Devils Fork Roadless Area, Scott County, Va. 
Appalachian Plateaus physiographic province. Most of the area is drained by Devil Fork and its tributaries. Clinch Rock Branch of Straight Creek, Roddy Branch of Valley Creek, and Stinking Creek, all tributary to the Clinch River, drain small fringe tracts. Altitudes range from about $1,550 \mathrm{ft}$ on the lower part of Straight Fork to about $3,490 \mathrm{ft}$ at Cox Place on Little Mountain. Vegetation varies from mixed hardwoods in the uplands to thickets of conifer, rhododendron, and laurel in moist protected areas, as in coves along drainage courses.

\section{Previous Investigations}

Early investigations in the Devils Fork area included geologic mapping and a description of coal occurrences (Campbell, 1893, 1894). Further study by Campbell and Woodruff (1909) indicated that the coal was of minor economic importance. Eby (1923) mapped the geology of Scott County and identified several coal beds in the Devils Fork area. Correlations of coal-bearing rocks in the southwestern Virginia coal field are presented by Wanless (1946), Gathright (1964), Englund and Delaney (1966), Miller (1969), Miller (1974), and Englund (1979). The results of test drilling for coal in nearby areas are summarized by Englund and others (1983), and Simon and Englund (1983).

\section{Present Investigations}

U.S. Bureau of Mines (USBM) field reconnaissance was conducted by P.T. Behum, L.E. Harris, and R.W. Hammack in the fall of 1979 and spring of 1981 (Behum, in press). They interviewed mine owners and examined coal prospects, outcrops, and active and abandoned mines. Where possible, coal samples were collected for analyses. A total of 45 channel, chip, and grab samples were taken in or near the roadless area. All samples were analyzed spectrographically for 40 elements by the USBM Reno Research Center, Reno, Nev. Atomic absorption, Xray fluorescence, radiometric, and chemical analyses were performed on selected samples. Clay and shale samples were evaluated for ceramic properties and lightweight-aggregate potential by the USBM Tuscaloosa Research Center, Tuscaloosa, Ala. Coal samples were analyzed by the U.S. Department of Energy, Division of Solid Fuel Mining and Preparation, Coal Analysis, Pittsburgh, $\mathrm{Pa}$.

U.S. Geological Survey (USGS) investigations were conducted in the fall of 1980 and spring of 1981 by K.J. Englund, W.R. Sigleo, A.H. Randall, and N.K. Teaford. These studies consisted of reconnaissance geologic mapping including mapping of a previously unrecognized fault at the eastern edge of the area, description of coal beds and stratigraphic sections, and altimeter surveys of the altitudes of mapped units, mines, and coal prospects (Englund and others, in press). In addition, A.E. Grosz, W.F. McCollough, and J.S. West collected 50 bulk samples of stream sediments and 24 representative rock samples that consisted of 16 sandstone and eight shale samples. These samples, with the exception of the panned concentrates, were analyzed semiquantitatively in USGS laboratories, Denver, Colo., for 31 elements, including metals having the greatest economic importance (Grosz and others, in press). The hydrocarbon potential of the study area was assessed by J.B. Roen.

\section{Acknowledgments}

The authors are grateful to mine owners and operators, property owners, and local prospectors for their generosity in supplying background information for this study. Appreciation is also extended to the U.S. Forest Service personnel, Atlanta, Ga. and Wise, Va., for providing land status and prospecting information.

\section{SURFACE- AND MINERAL-RIGHTS OWNERSHIP}

Surface rights for about 80 percent of the Devils Fork Roadless Area are in Federal ownership. The remaining surface acreage and all of the mineral rights are in private ownersip (fig. 2).

The largest land tract in Federal surface ownership (2,977 acres) was purchased in 1938 from the Mineral Development Company and others (fig. 2). Two road rights-of-way and all coal, oil, gas, and other minerals were retained, along with the right to mine, prospect, and drill for these minerals, subject to rules and regulations of the Secretary of Agriculture. These mineral rights were leased to P.C. Southworth, who subsequently applied for a special-use permit from the U.S. Forest Service to improve a portion of an abandoned road to serve as a service area for mining and to face up an exposed coal bed.

Mineral rights were retained on acreage at the west edge of the area by Maple Gap Coal Corporation (fig. 2). Maple Gap had leased mineral rights in this area continuously since about 1933 . These mineral rights were subsequently sold in 1977 to Park Cool Company, Inc., of Kingsport, Tenn., which currently lease the right to mine the Cove Creek coal bed and all overlying coal beds to Flannagan Energy, Ltd., of Bristol, Va.

Surf ace rights of two tracts on the eastern edge of the study area were purchased from the Hagen Estates, Inc., which retained all of the mineral rights in perpetuity. No leasing is known to have occurred on these tracts. Another tract was purchased from H. K. Morrison and others, with minerals also retained (fig. 2).

Surface-rights ownership of private tracts within the roadless area is in dispute and is uncertain. However, from information gathered during interviews with local landowners conducted at the time of the study, the ownership is aproximately as shown in figure 2. No oil and gas leases were held in the study area in 1983 , but an active lease was held on a nearby iract (2A, fig. 2) by George E. Howard of Gate City, Va.

\section{GEOLOGY}

About $1,700 \mathrm{ft}$ of sedimentary rocks of Late Mississippian to Early Pennsylvanian age crop out in the study area (Englund and others, in press) and as much as $14,000 \mathrm{ft}$ of older Paleozoic rocks may be present in the subsurface. The basal part of the exposed section crops out in the belt of faulted and overturned rocks at the southeastern edge of the study area and consists of shallow marine to supratidal rocks assigned to the Bluestone Formation of Late Mississippian to Early Pennsylvanian age. The rest of the exposed section consists mostly of continental, coal-bearing rocks of the Lower Pennsylvanian Pocahontas and Lee Formations. The Pocahontas crops out only in the belt of overturned beds and the 


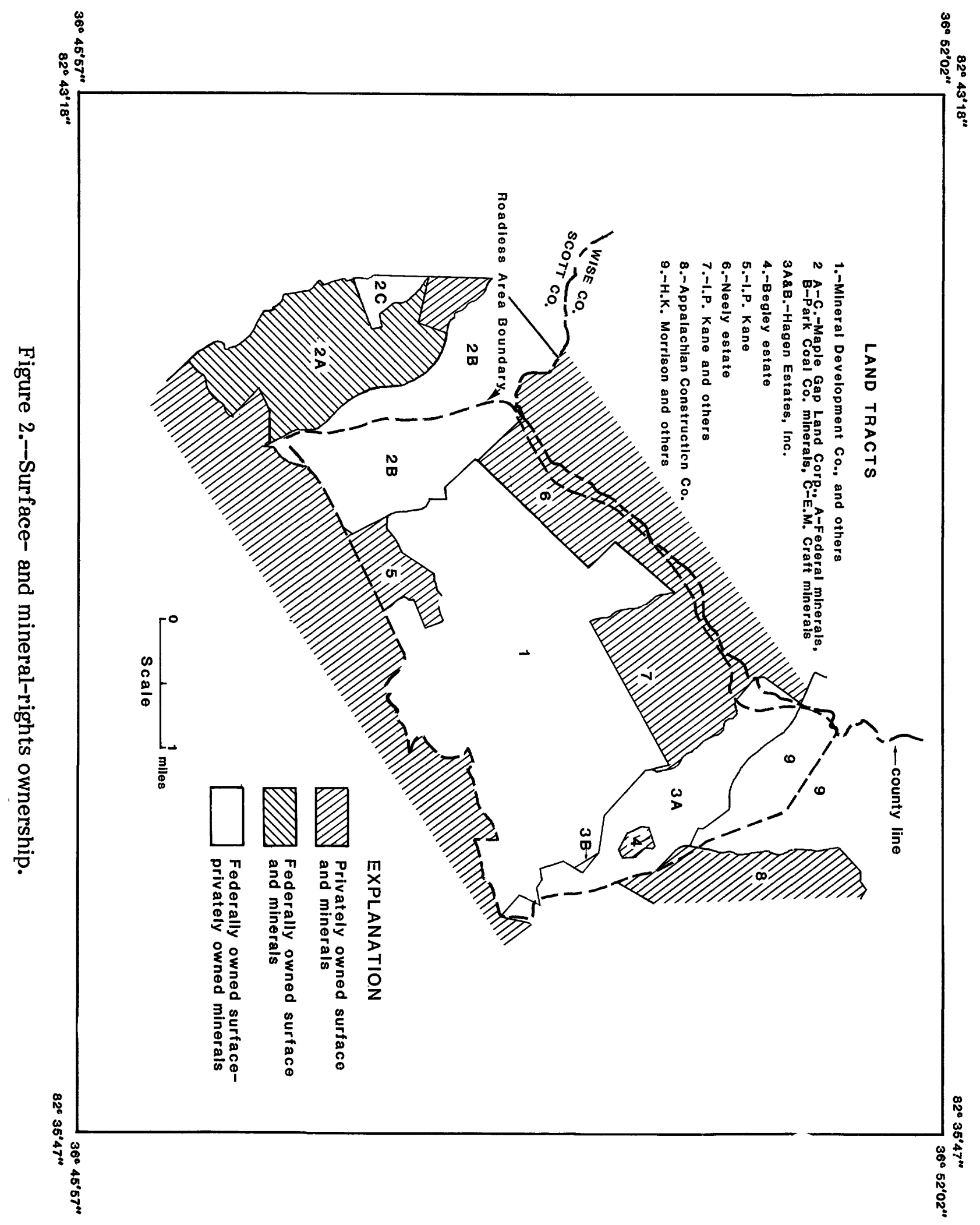


Lee is present along the northern edge of this belt and in the remainder of the area to the northwest (Englund and others, in press). Unmapped surficial deposits consist of locally derived colluvium on valley slopes and alluvium on valley floors.

The basal $500 \mathrm{ft}$ of the exposed section, assigned to the Bluestone Formation, consists of darkgray, evenly bedded shale grading locally into silty shale or interlaminated sandstone, siltstone, and shale. Overlying beds are mostly grayish-red to greenish-gray, partly calcareous shale, siltstone, and sandstone with minor amounts of argillaceous limestone and carbonaceous shale. The Bramwell Member, a marine unit near the top of the formation, is dark-gray shale grading locally into silty shale or very fine-grained sandstone. The base of the Bramwell is at a persistent thin bed of coal or carbonaceous shale containing abundant ostracodes. Overlying beds of the member contain locally abundant invertebrate fossils.

The Pocahontas Formation conformably overlies the Bluestone and consists of about $100 \mathrm{ft}$ of light- to medium-light-gray sandstone interbedded with siltstone, shale, coal, and underclay. Depositional trends and fossil content indicate that the Pocahontas was deposited in a deltaic and lagoonal setting.

The Lee Formation comprises the uppermost $1,100 \mathrm{ft}$ of the rocks exposed in the study area and consists of two thick tongues of medium- to coarsegrained sandstone that is partly conglomeratic, separated by about $600 \mathrm{ft}$ of a coal-bearing sequence of interbedded shale, siltstone, fine-grained sandstone, and underclay. The principal coal beds of this sequence are the Cove Creek, Stock Creek, C-1, C-2, and $\mathrm{C}-4$ beds. The names Cove Creek and Stock Creek are from previous studies of the area. The designations $\mathrm{C}-1$ through $\mathrm{C}-6$ are applied informally to uncorrelated coal beds.

Quaternary deposits consist of sandstone and conglomeratic sandstone debris occurring in colluvium on the valley slopes and in alluvium on the valley floors.

The Devils Fork Roadless Area lies on the southern limb of the Powell Valley anticline. Strata of this structure dip between 6 and $20^{\circ}$ to the southeast. A northeast-striking thrust fault in the southeastern part of the study area is associated with the nearby Hunter Valley thrust fault, a major feature which has caused overturning and repetition of strata. There, the beds are overturned and dip 35 to $55^{\circ}$ to the southeast. A north-northwest-trending strike-slip fault having apparent minor vertical and horizontal displacements was observed locally along Straight Fork near the eastern boundary of the study area.

\section{ASSESSMENT OF MINERAL RESOURCE POTENTIAL}

Potential mineral resources in the Devils Fork Roadless Area consist of coal, oil and gas, limestone, clay, shale, and sandstone. Of these, coal of highvolatile $A$ bituminous rank is the principal mineral resource. It has been prospected extensively and mined on a small scale within and near the northeastern and southwestern boundaries of the area. Development of the remaining reserves may be limited by accessibility, extraction costs, and constraints imposed on mining by environmental legislation. The potential for oil and gas is unproven. However, nearby drilling indicates that formations underlying the study area have moderate to high potential for gas and a low potential for oil. Highcalcium limestone crops out immediately to the southeast and underlies the study area at depth where underground mining operations may not be feasible. Clay and shale cropping out in the area are suitable for various structural-clay products and some beds display bloating characteristics that may be marginally adequate for the manufacture of lightweight aggregate. Metallic-mineral deposits have not been identified in the area and major chemical anomalies were not detected in geochemical surveys for the occurrence of such deposits (Grosz and others, in press).

\section{Coal}

Coal occurs in the study area in as many as 18 beds, ranging from a few inches to about $4 \mathrm{ft}$ in thickness. Six of these beds-the Squire Jim coal bed in the Pocohantas Formation and the Cove Creek, Stock Creek, C-1, C-2, and C-4 coal beds in the Lee Formation-are of sufficient thickness, extent, and quality for the estimation of resources (table 1). Remaining resources total approximately 35 million short tons for the six beds and an additional 420 thousand short tons are estimated to have been mined or lost in mining from the Cove Creek coal bed. Of the estimated total remaining resources, 72 percent is in the 14-28 in. category, 27 percent is in the 28-42 in. category, and less than 1 percent is in the $>42$ in. category. The Cove Creek coal, the thickest and most important bed, contains 3.9 million short tons of coal, or 11 percent of the remaining coal resources. The demonstrated reserve base for coal beds within the roadless area is 4.57 million short tons (table 2). Assuming a 60 percent recovery factor, 2.7 million short tons are estimated for the demonstrated reserves. If surface mining were permitted, an additional 132 thousand short tons may be accessible. Most estimated remaining coal resources and reserves are located in the southwestern and northeastern thirds of the roadless area (figs. 3 and 4). Analyses of coal cores from nearby areas of Scott County show that the coal is of high-volatile A bituminous rank (Englund and others, 1983, Simon and Englund, 1983). On an as-received basis, sampled coal in the Pocahontas Formation is low in sulfur ( $<0.7$ percent), low in ash $(<8.0$ percent), and high in heating value $(>13,000 \mathrm{Btu} / \mathrm{lb}$ ) (table 3). Analyses of the Cove Creek coal bed showed similar results except for one sample with a high ash content. Thin splits of the Little Fire Creek coal bed are high in sulfur, moderate to high in ash, and high in heating value.

The trace element and major and minor oxide contents of both laboratory coal ash and whole coal do not indicate significant amounts of either potentially toxic or economically valuable trace elements.

Squire Jim coal bed-A widely distributed coal occurring 35 to $40 \mathrm{ft}$ above the MississippianPennsylvanian boundary is identified as the Squire Jim coal bed on the basis of its stratigraphic position. It is at a depth of about $1,000 \mathrm{ft}$ in the roadless area. Data are available only from outcrop and drill holes in nearby areas which indicate that the bed generally increases in thickness to the east and southeast, possibly to 28 in. or more. 


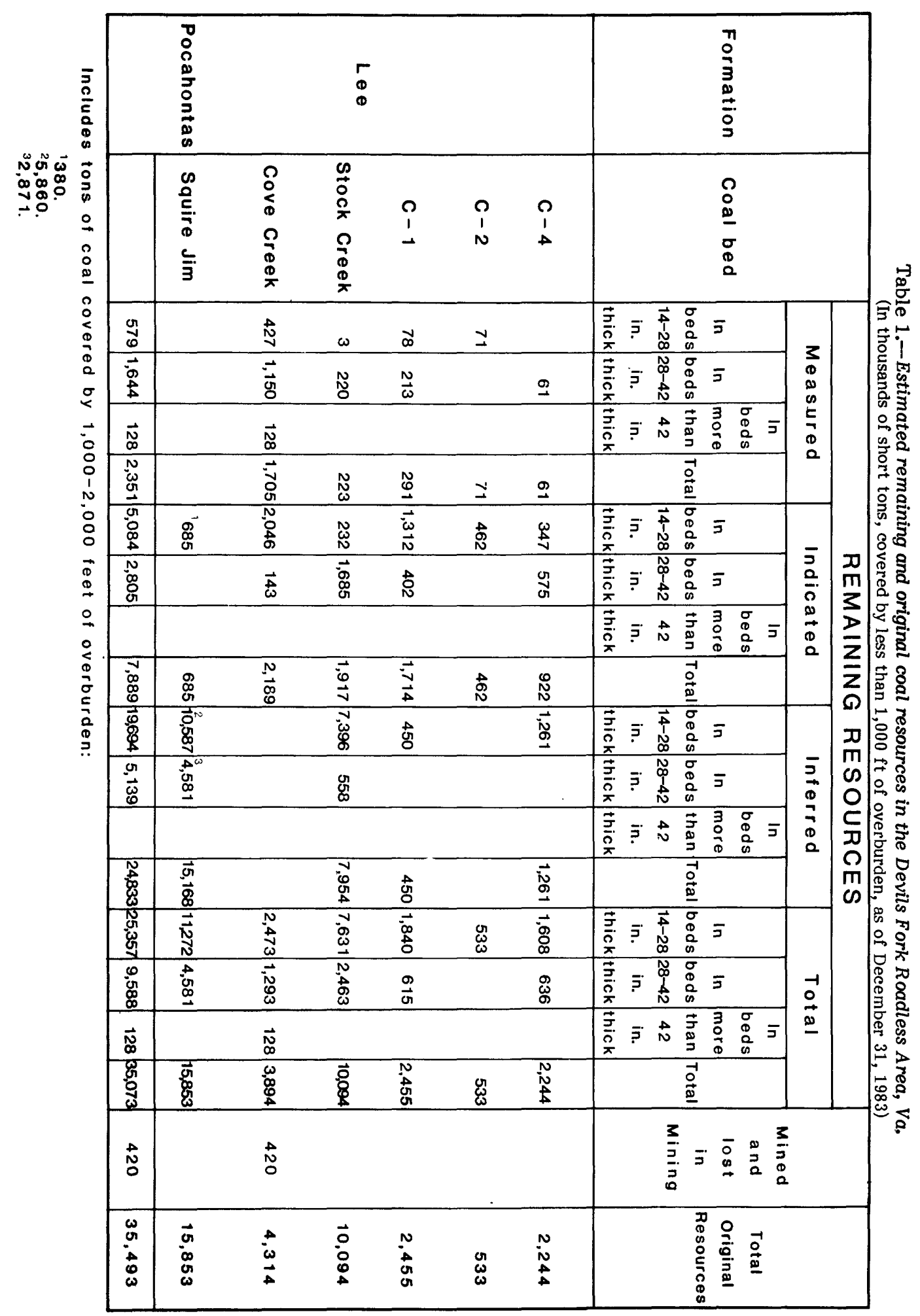




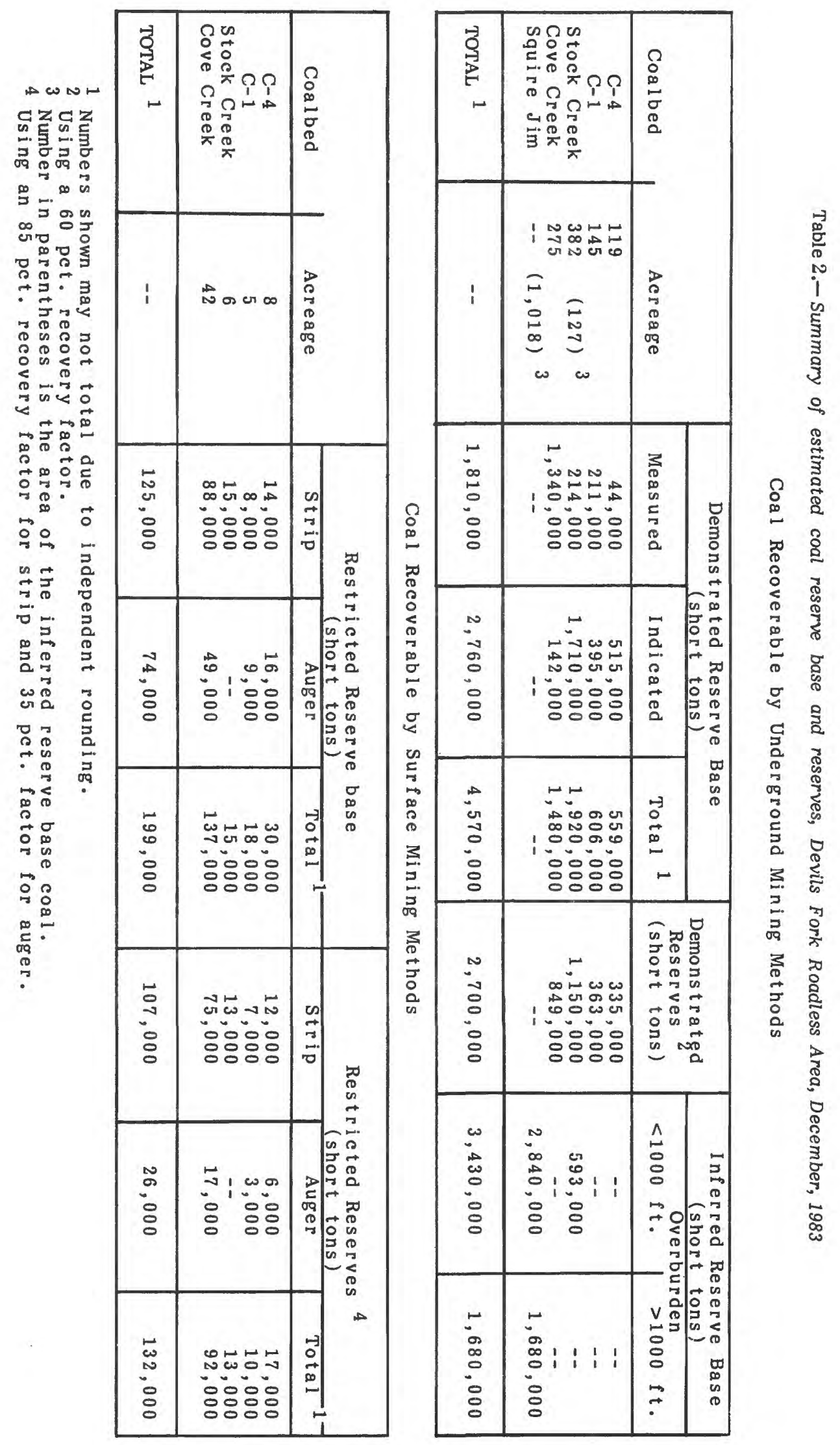




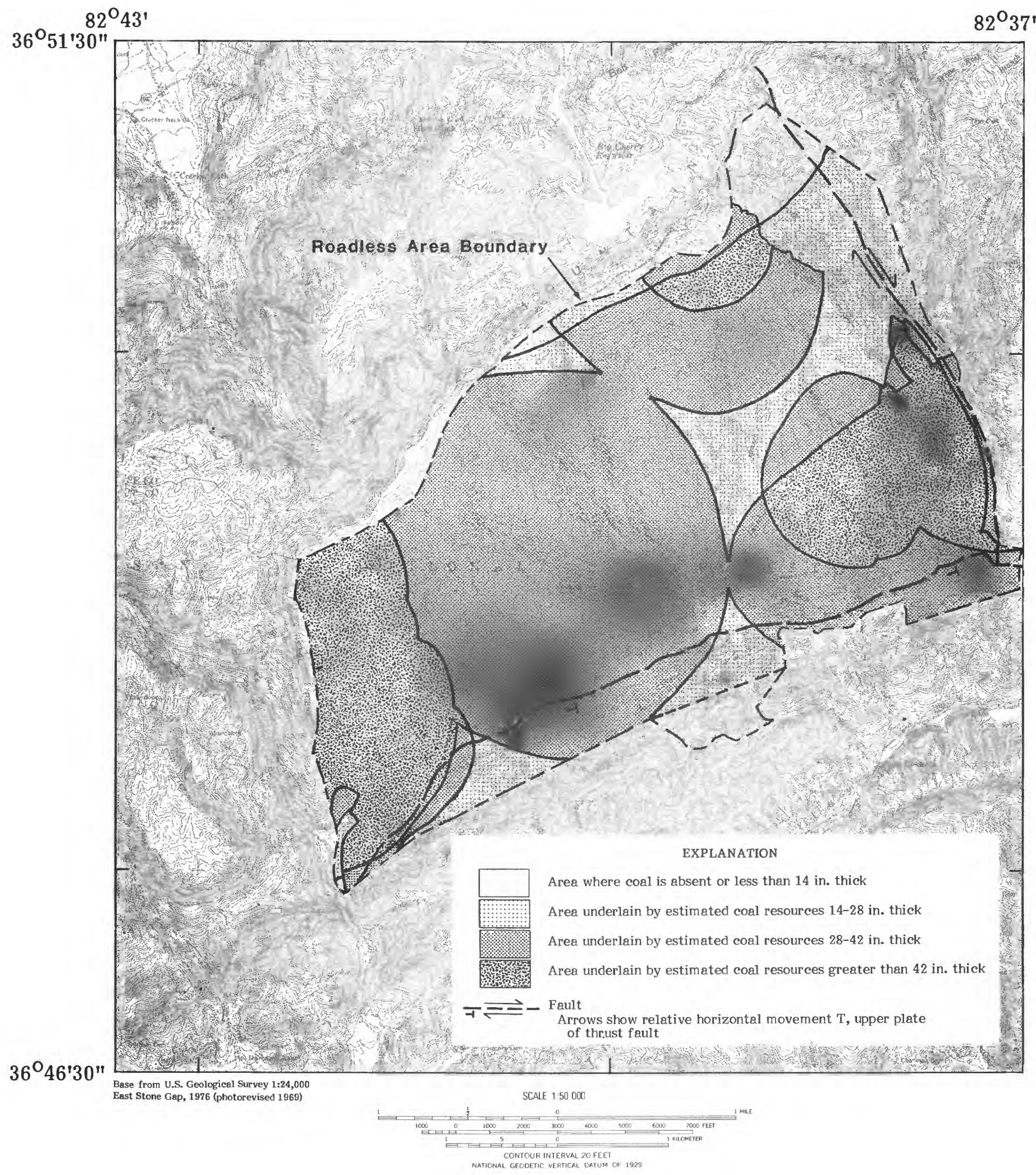

Figure 3.--Cumulative known coal-resource distribution. 


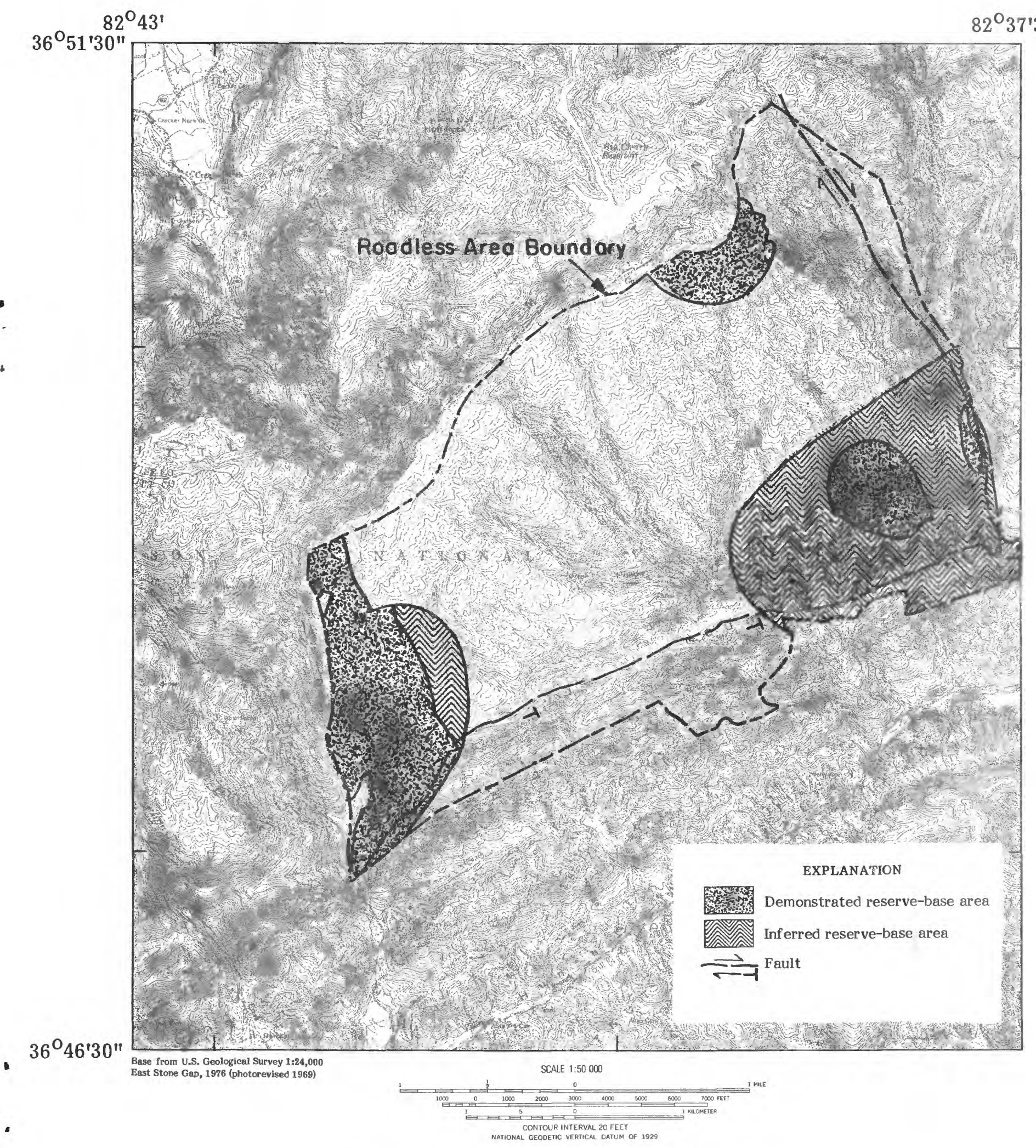

Figure 4.--Composite coal reserve base area. 


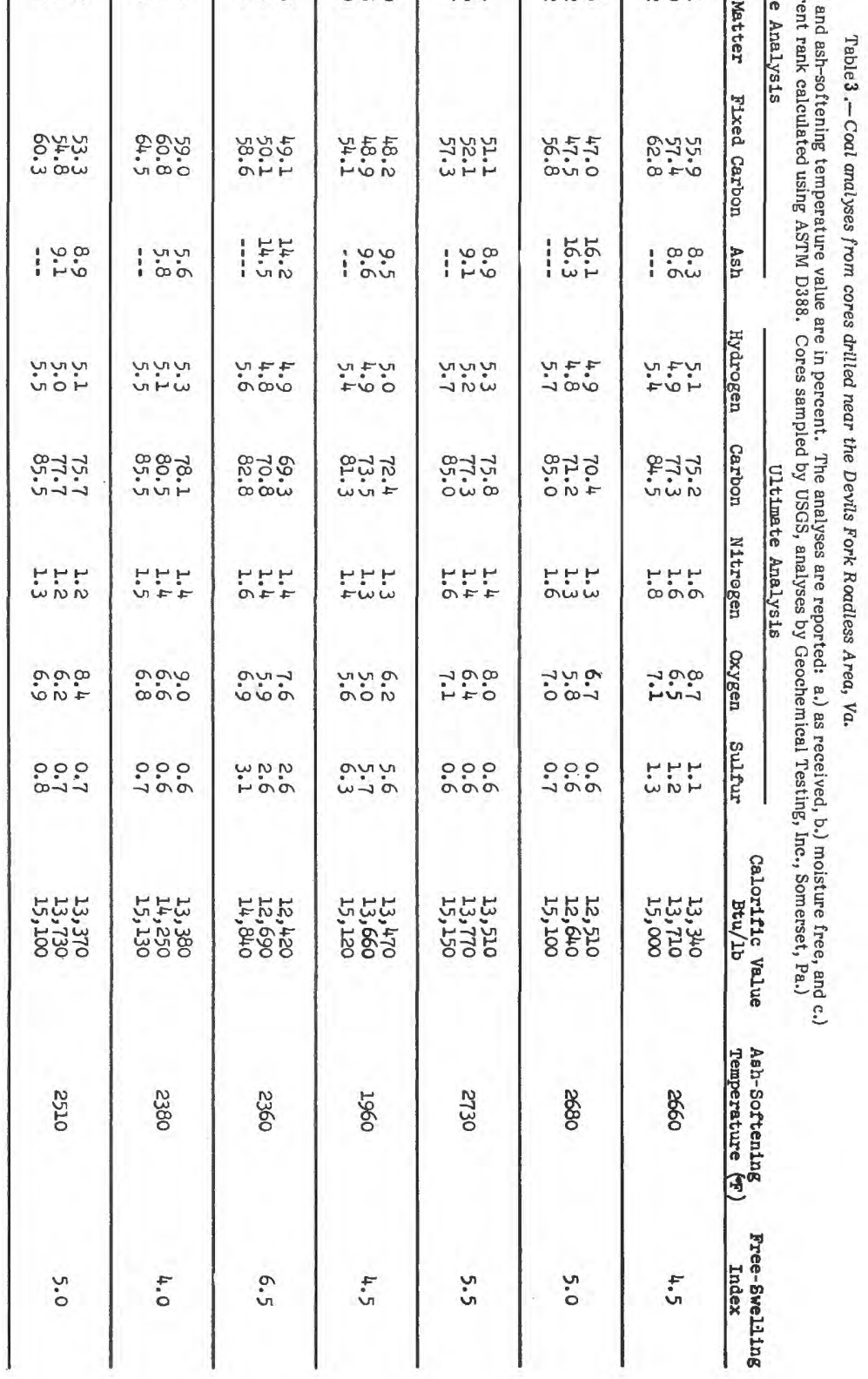


Cove Creek coal bed-the Cove Creek coal bed occurs immediately above a thick conglomeratic orthoquartizite assigned to the lower sandstone tongue of the Middesboro Member of the Lee Formation. The coal bed is 42 in. or more thick along the western edge of the area where it has been mined from drift entries along Cove creek, about $0.25 \mathrm{mi}$ to the west. At the eastern edge of the area, the Cove Creek coal bed crops out along Straight Fork where it attains a maximum thickness of about 29 in. East of the area the bed has been extensively mined and is known locally as the Starns coal bed. Data are lacking in the central part of the area where the bed is entirely in the subsurface and is presumed to be relatively thin.

Stock Creek coal bed-The Stock Creek coal bed crops out about $100 \mathrm{ft}$ above the Cove Creek coal along the western and eastern edges of the area. Along Cove Creek, the Stock Creek coal bed is as much as 48 in. thick and has been strip mined on a small scale about $0.25 \mathrm{mi}$ west of the area. It is about $16 \mathrm{in}$. or less thick in outcrops along Straight Fork at the eastern edge of the area.

C-1 to C-6 coal beds-Several unnamed coal beds that lie from 100 to $400 \mathrm{ft}$ above the Stock Creek coal bed are tentatively designated $\mathrm{C}-1$ to $\mathrm{C}-6$. Of these, the $\mathrm{C}-1, \mathrm{C}-2$, and $\mathrm{C}-4$ are of sufficient thickness and extent to contain estimated resources. The $\mathrm{C}-1$ coal bed contains resources locally in the 14-28 in. thickness category at the western edge of the area. Resources in the 14-28 in. and 28-42 in. thickness categories near the eastern edge have been developed on a small scale at an abandoned truck mine where the coal is 29 in. thick. The $\mathrm{C}-2$ coal bed contains resources in the 14-28 in. thickness category near the western edge of the study area and the C-4 coal bed contains resources in the 14-28 and 28-42 in. categories in the northeastern part.

\section{Oil and Gas}

Sedimentary rocks underlying the Devils Fork Roadless Area are similar to those in nearby areas that contain commercial quantities of oil and gas. According to J. B. Roen (USGS, Reston, Va., 1983, written commun.) the area is: 1) underlain by source rocks containing sufficient organic material for the generation of oil and gas; 2) the maturation level as determined by various indicies, such as fixed carbon ratios and coal rank, indicates that the rocks have been subjected to thermal alteration that is at or exceeds the upper level for oil generation but is well within the temperature range for the generation of gas; and 3) reservoirs, in addition to conventional stratigraphic traps, may have developed at the southeastern edge of the area in the footwall of the Hunters Valley thrust fault where faulting may have produced the necessary fracture porosity, permeability, and structural seals for the entrapment of gas. Test wells for oil or gas have not been drilled in the roadless area. However, five test wells have been drilled within $8 \mathrm{mi}$ of the area. Of these, two are productive shut-in gas wells and three have been plugged and abandoned.

On the basis of these results, J. B. Roen (1983, written commun.) concluded that rocks underlying the Devils Fork Roadless Area have a low potential for oil and a moderate to high potential for gas, particularly where Ordovician, Devonian, and Mississippian rocks have been deformed and fractured near the Hunter Valley thrust fault.

\section{Shale}

Preliminary ceramic tests of five samples from the Lee Formation indicate that clay or shale beds in the formation may be suitable for structural clay products. Analysis of a sample of the roof shale of the Stock Creek coal bed indicates that it may be marginally suitable for the manufacture of lightweight aggregate. Because of the remoteness of the area, low unit value, and low demand, clay and shale beds in the roadless area would probably not be mined in the foreseeable future.

\section{Sandstone}

Sandstone is the predominate rock type cropping out in the study area and it has limited use as rough building stone and roadstone. Highly weathered and friable portions may be useful for various construction and special-purpose sands. In general, commercial utilization of this sandstone is unlikely because more accessible and probably better quality deposits are available outside the area.

\section{REFERENCES CITED}

Behum, P.T., in press, Mines, prospects, and exposures in the Devils Fork Roadless Area, Scott County, Virginia: U.S. Geological Survey Miscellaneous Field Studies Map MF-1611-D, scale 1:50,000.

Campbell, M.R.,1893, Geology of the Big Stone Gap coal field of Virginia and Kentucky: U.S. Geological Survey Bulletin 111, 106 p.

1894, Description of the Estillville sheet, Kentucky-Virginia-Tennessee : U.S. Geological Survey Geological Atlas, Folio 12, 5 p.

Campbell, M.R., and Woodruff,E.G., 1911, The Powell Mountain coal field, Scott and Wise Counties, Virginia, in Campbell, M.R., Contributions to Economic Geology, 1909, Part II: U.S. Geological Survey Bulletin 431, p. 147-162.

Eby, J.B., 1923, The geology and mineral resources of Wise county and the coal-bearing portion of Scott County, Virginia: Virginia Geologic Survey Bulletin 24, 617 p.

Englund, K.J., 1979, The Mississippian and Pennsylvanian (Carboniferous) Systems in the United States - Virginia: U.S. Geological Survey Professional Paper 1110-C, 21 p.

Englund, K.J., and DeLaney, A.O., 1966, Intertonguing relations of the Lee Formation in southwestern Virginia in Geological Survey research, 1966: U.S. Geological Survey Professional Paper 550D, p. D47-D52.

Englund, K.J., McKibbin, T.M., and Sigleo, W.R., in press, Geologic map of the Devils Fork Roadless Area, Scott County, Virginia: U.S. Geological Survey Miscellaneous Field Studies Map MF1611-A, scale 1:24,000.

Englund, K.J., Windolph, J.F., Jr., Weber, J.C., Thomas, R.E., and Dryden, J.W., 1983, Test drilling for coal in 1982-83 in the Jefferson National Forest, Virginia, Part 1-Lithologic descriptions and geophysical logs of coreholes in the southwestern Virginia coal field, Dickenson, 
Lee, Scott, and Wise Counties, Virginia: U.S. Geological Survey Open-File Report 83-628, 374 p.

Gathright, T.M., Jr., 1964, Revision of the Lower Pennsylvanian correlations in Wise County, Virginia: Virginia Journal of Science, Volume 15, Number 4, p. 331-332.

Grosz, A.E., Cooley, E.F., and McCollough, W.F., in press, Geochemical survey of the Devils Fork Roadless Area, Scott County, Virginia: U.S. Geological Survey Miscellaneous Field Studies Map MF-1611-B, scale 1:50,000.

Miller, M.S., 1974, Stratigraphy and coal beds of Upper Mississippian and Lower Pennsylvanian rocks in southwestern Virginia; Virginia Division of Mineral Resources Bulletin 84, 211 p.

Miller, R.L., 1969, Pennsylvanian formations of southwest Virginia: U.S. Geological Survey Bulletin 1280, 62 p.

Simon, F.O., and Englund, K.J., 1983, Test drilling for coal in 1982-83 in the Jefferson National Forest, Virginia; Part 2-Analyses of coal cores from the southwestern Virginia coal field: U.S. Geological Survey Open-File Report 83-620, $23 \mathrm{p}$.

Wanless, H.R., 1946, Pennsylvanian geology of a part of the southern Appalachian coalfield: Geological Society of America Memoir 13, 162 p. 